\title{
Danza, política y subversión utópica: la Consagración de la primavera de Oscar Aráiz y Fedra de Ana Itelman (1968-1970)
}

( Juan Ignacio Vallejos

CONICET, Universidad de Buenos Aires, Argentina

juanigvallejos@gmail.com

Fecha de recepción: 18/08/2020. Fecha de aceptación: 29/09/2020

\begin{abstract}
Resumen
A través de un estudio de los intentos de censura de las obras de danza contemporánea Consagración de la Primavera de Oscar Aráiz y Fedra de Ana Itelman, intentaremos analizar el lugar que ocuparon estas prácticas artísticas en el contexto de contestación social generalizada característico de fines de la década del 60 en Argentina. Se tratará de analizar su potencialidad crítica a partir de la figura de una subversión utópica asociada a una disputa por la sexualidad, por la recuperación del cuerpo, y por la construcción de subjetividad frente al poder dictatorial. En última medida, el trabajo buscará reflexionar acerca de la politicidad de las obras de danza, es decir, de su capacidad de intervención política en un contexto histórico específico, señalando al mismo tiempo la diferencia entre arte militante y arte político.
\end{abstract}

Palabras clave: Danza Contemporánea y Política, Onganiato, Censura, Consagración de la Primavera, Aráiz , Fedra, Itelman.

Dance, politics and utopian subversion: The Rite of Spring by Oscar Aráiz and Phaedra by Ana Itelman (1968-1970).

\begin{abstract}
Based on a study of the attempts to censor the contemporary dance works The Rite of Spring by Oscar Aráiz and Phaedra by Ana Itelman, we will try to analyze the role played by these artistic practices in the context of the widespread social protest which characterizes the late 1960 s in Argentina. The aim is to analyze its critical potentiality on the basis of the model of a utopian subversion associated with a dispute over sexuality, the recovery of the body and the construction of subjectivity in the face of dictatorial power. Ultimately, the work will seek to reflect on the politicity of dance works, that is, on their ability for a political
\end{abstract}


intervention in a specific historical context, while pointing out the difference between militant art and political art.

Keywords: Contemporary Dance and Politics, Onganiato, Censorship, Aráiz, Itelman, The Rite of Spring, Phaedra

El siguiente trabajo se propone contribuir al estudio de la historia de la danza contemporánea en la Ciudad de Buenos Aires ${ }^{1}$. Creemos que un elemento definitorio del modo en que se desarrollaron las prácticas dancísticas en la ciudad, al menos durante el periodo que va desde los años 60 hasta la posdictadura de los años 1980, ha sido la constante confrontación de los actores del campo artístico con la política, entendida en sentido amplio. Las prácticas artísticas debieron amoldarse a un contexto de inestabilidad institucional ligado a la fragilidad del orden democrático, a los sucesivos golpes de estado, al control social y a las variadas formas del terrorismo de Estado ejercido por los gobiernos autoritarios. A través de un estudio sobre la repercusión que obtuvieron, entre 1968 y 1970, dos obras de danza contemporánea presentadas por el Ballet del Teatro San Martín, Consagración de la Primavera de Oscar Aráiz y Fedra de Ana Itelman, intentaremos analizar el lugar que estas prácticas ocuparon en un contexto de contestación social generalizada. En última medida, el trabajo buscará reflexionar acerca de la politicidad de las obras de danza, es decir, de su capacidad de intervención política en un contexto histórico específico, señalando al mismo tiempo la diferencia entre arte militante y arte político.

\section{Dictadura y subversión utópica}

El 28 de junio de 1966, en Argentina, tiene lugar un golpe de estado, liderado por el militar Juan Carlos Onganía, que derroca al presidente democrático Arturo Illia. Se trata del cuarto golpe de estado contra un gobierno constitucional desde 1930. La nueva dictadura se autodenomina "Revolución Argentina" y se presenta como un gobierno que busca instalarse de manera prolongada en el poder a fin de modificar sustancialmente las condiciones económicas, sociales y culturales. El golpe surge bajo la influencia de lo que se conoce como la Doctrina de la Seguridad Nacional ligada a diversas acciones de política exterior del gobierno de EE.UU. tendientes a impedir el avance del comunismo en Latinoamérica después de la revolución cubana y en el marco de la Guerra Fría con la Unión Soviética. En ese sentido, el nuevo gobierno dictatorial se caracteriza por una ideología fuertemente anticomunista.

Las prácticas de control y represión por parte de la dictadura de Onganía son resistidas desde diversos espacios, tanto desde el movimiento obrero y la militancia política, como desde las Universidades y el campo de la cultura. Tres años después del golpe, en mayo de 1969, se produce una insurrección popular en la ciudad de Córdoba, conocida como el Cordobazo, que debilita el liderazgo del dictador Juan Carlos Onganía hacia dentro de la elite militar. En los años siguientes, tiene lugar una progresiva radicalización de la militancia política, es decir, que una parte de los militantes comienza a ver a la lucha armada como la única opción para lograr el regreso de la democracia y generar un cambio profundo en la sociedad. Existía un clima triunfalista, arraigado en amplios sectores de la militancia, que afirmaba la inminencia o la proximidad real de una revolución, algo que representaba para la época la sensación de estar viviendo "un cambio tajante e inminente en todos los órdenes de la vida" (Longoni 2014, 22).

1 El presente trabajo es una versión revisada y ampliada del artículo "Dance, Sexuality and Utopian Subversion Under the Argentine Dictatorship of the 1960s" publicado en la revista Dance Research Journal 48/2, 2016. También fue publicada una versión algo resumida en francés en el libro Danser en 68: Perspectives Internationales, dirigido por Isabelle Launay, Sylviane Pagès, Mélanie Papin y Guillaume Sintès, Deuxième Époque, 2018. 
1970 es el año en el que las organizaciones guerrilleras comienzan a actuar abiertamente generando una fuerte crisis en el gobierno autoritario. El dictador Onganía es reemplazado en el mes de junio por el militar Roberto Marcelo Levingston. Los primeros años de esa década constituyen uno de los momentos de mayor efervescencia política en toda la historia argentina. Desde la sociología se tiende a definir ese momento histórico como el de una "contestación social generalizada" que produce una situación de ingobernabilidad social. Como respuesta a esta situación extrema el gobierno autoritario decide llamar a elecciones democráticas, se determina el fin de la proscripción del peronismo y como consecuencia se produce la vuelta de Juan Domingo Perón al país en 1973. La socióloga María Cristina Tortti (1999) afirma que el regreso de Perón al poder, con un programa reformista, no representó un triunfo de la revolución, sino la única vía que las clases dominantes encontraron para evitar el desarrollo de un verdadero proceso revolucionario. Es una hipótesis algo incomprobable, ya que una gran parte de aquella masa revolucionaria sostenía como principal reclamo la vuelta Perón. Quizás, el problema estaría en vislumbrar las diferencias entre el Perón que se quería de vuelta y el que realmente regresó. En todo caso, lo que resulta indiscutible es que se trata de uno de los momentos de mayor convulsión social en la historia del país.

En este mismo contexto de contestación generalizada emergen los primeros movimientos por los derechos civiles. 1970 es el año en el que nace la Unión Feminista Argentina que es la primera agrupación feminista del país. Luego, en 1972, se funda también el Movimiento de Liberación Femenina (Calvera, 1990; Andújar, 2009). Paralelamente, se crea en 1971 el Frente de Liberación Homosexual. Como sostiene el poeta y sociólogo Néstor Perlongher, miembro fundador del Frente, esta organización política encarnaba el deseo de una minoría de homosexuales "de participar en un proceso de cambio presuntamente revolucionario, desde un lugar en el que sus propias condiciones vitales y sexuales pudieran ser planteadas" (2008: 78). De este modo, podemos afirmar que el momento de efervescencia social que caracteriza a los primeros años de la década del 70, excede el plano de lo político partidario. Los movimientos a los que hacemos alusión emergen en el terreno de una cultura juvenil en búsqueda de una mayor libertad individual que asume el sexo como una herramienta para llevar adelante un cambio moral y, por ende, en las subjetividades.

La radicalización política también tiene una expresión directa en el terreno de las artes plásticas. Longoni y Mestman describen el recorrido de un grupo de artistas que, en 1968, llevan adelante una ruptura con las instituciones artísticas, fundamentalmente con el Instituto Di Tella, asumiendo una actitud de oposición directa al gobierno militar. La expresión más conocida de este movimiento es la obra colectiva Tucumán Arde que tiene lugar a fines de ese mismo año (2002: 21). Según Longoni, existe un primer periodo en el que ciertos artistas plásticos buscan generar un efecto directo en la esfera política a través de sus obras. Sin embargo, en el nuevo período que comienza en 1969, la aceptación de la violencia revolucionaria como único camino de transformación los lleva a cuestionar lisa y llanamente el sentido del arte (Longoni, 2014: 54). En consecuencia, muchos de ellos abandonan sus prácticas estéticas para sumarse a la lucha armada. De este modo, el proceso de contestación generalizado llega, en ciertos casos, a anular la práctica artística. El cuestionamiento del poder, característico de este momento, abarca entonces planos diversos y trascendentales como el sistema político, la producción de subjetividad en sus condiciones vitales y sexuales, y el sentido mismo de la práctica artística.

Es este el contexto en el que se presentan las obras analizadas en este artículo, un contexto de contestación y de redefinición generalizada de prácticas sociales, culturales y políticas. Sin embargo, es necesario señalar que Oscar Aráiz y Ana Itelman no formaron parte de esa juventud radicalizada. Ellos no cortaron su vínculo con 
las instituciones artísticas por razones ideológicas, como sí lo hicieron los artistas estudiados por Longoni y Mestman. Tampoco asumieron explícitamente un discurso opuesto a la dictadura, ni participaron activamente en la militancia política. No obstante, según intentaremos demostrar, sus obras intervinieron políticamente, aunque de un modo particular. Como sostiene Mark Franko, "las políticas no se ubican directamente 'en' la danza, sino en la forma en que la danza logra ocupar el espacio (cultural)" (2019: 206). Nuestro análisis buscará, en este sentido, estudiar la representación escénica como acción, es decir, la puesta en escena de una obra comprendida como una intervención social, cuyo sentido político no se establece únicamente a partir de la voluntad explícita de su creador, sino que emerge de la recepción de la cual la misma es objeto. Nuestra idea de acción está en cierto modo inspirada por la idea de "escritura como acción" planteada por el historiador Christian Jouhaud (2009: 40). La obra adquiere sentido a partir de los efectos de su intervención en el entramado de relaciones de poder que la contiene.

En este sentido, nuestro trabajo sobre la politicidad del arte supone una reconsideración de la figura del artista militante. Como veremos más adelante, no son exclusivamente los coreógrafos los encargados de otorgar un contenido político a sus obras. A diferencia de los artistas estudiados por Longoni y Mestman, que asumen explícitamente una posición política de manera personal, en el caso de Consagración y Fedra el contenido político emerge como un efecto del acontecimiento escénico. Las autoridades de los teatros, ligadas al gobierno dictatorial que las censuran, así como el periodismo que las reivindica, son actores que otorgan contenido político a las obras más allá de las intenciones explícitas de los artistas. En cierto modo, se trata de visibilizar lo que diferencia al arte militante del arte político, es decir, al arte que promueve un determinado discurso político (visual, textual o cinético) de aquel que ocasiona voluntaria o involuntariamente un acontecimiento político. Claramente, no son categorías opuestas, sino dos niveles de análisis distintos que confluyen y expresan la relación histórica entre arte y política.

La centralidad del autoritarismo durante el periodo histórico estudiado hace que la politicidad de las representaciones escénicas esté determinada por la ideología del aparato estatal. En este sentido, resulta fundamental dar cuenta de las categorías que la dictadura utiliza para interpretar las acciones políticas opuestas al régimen. En su estudio sobre la censura, Invernizzi y Gociol (2003) sintetizan la distinción conceptual, realizada por los servicios de inteligencia, entre marxismo y subversión. Para definir algo como marxista, los analistas de los servicios buscaban en las publicaciones referencias directas como "lucha de clases", "materialismo dialéctico" o la presencia de nombres clave como Marx, Engels, Che Guevara, Lenin, Trotski o, incluso, Marcuse o Antonio Gramsci. Sin embargo, para definir algo como subversivo, se utilizaban categorías mucho más amplias y heterogéneas como: "cuestionamiento del orden familiar", "sindicalización", "aborto", "libertad sexual" o "teología de la liberación" (Invernizzi y Gociol, 2003: 50). De este modo, si la categoría de marxista apunta a la existencia de un programa teórico político definido, la categoría de subversión es atribuida a ideas o prácticas difusas que, sin embargo, son percibidas como cuestionamientos del orden político, social y cultural. El concepto de subversión supone la existencia de formas de intervención políticas que actúan en el plano de la subjetividad, de la ética, y en el terreno de lo sensible. De este modo, una obra de danza podía ser claramente considerada como subversiva, es decir, como una acción tendiente a alterar el orden establecido en esos planos.

Ahora bien, en Consagración de la Primavera y Fedra, observamos un elemento que puede funcionar como clave interpretativa en este sentido. Ambas obras movilizan implícitamente la figura de lo utópico, del nulle part, de un espacio inexistente desde el cual se proyectan gestos, cuerpos y discursos capaces de desafiar dispositivos 
fundamentales del poder como la dominación patriarcal o la moral católica. De este modo, proponemos la figura de una subversión utópica que toma la escena como un espacio de ficción política, entendiendo la ficción no como una forma de escapar de la realidad, sino como un espacio para la reconstrucción de lo real (Fiadeiro y Caspao, 2016: 202-203). En su libro Ideología y Utopía, Paul Ricoeur sostiene que a través de la utopía pueden repensarse de un modo radical cuestiones fundamentales como la familia, el consumo, la autoridad o la religión. En este sentido, afirma que la imaginación de otra sociedad posee una innegable capacidad de contestación (1997: 36). A partir de los conceptos desarrollados por Jill Dolan (2005) y José Esteban Muñoz (2009), mi propósito será analizar el contenido utópico de las representaciones escénicas de las obras de danza citadas, considerándolas, a su vez, como acontecimientos políticos.

Antes de proceder al análisis de las obras a partir de la hipótesis planteada, expondré dos temas que considero centrales para comprender la producción artística en el periodo. El primero se relaciona con el lugar que ocuparon las prácticas de danza en el marco de la cultura juvenil. Como veremos, las creaciones de danza estudiadas se desarrollaron en una doble tensión: por un lado, con respecto al régimen autoritario y, por el otro, con respecto a la militancia política tradicional. El segundo tema se refiere al modo en el que se ejerció la censura durante el gobierno de Onganía. Más allá de su anticomunismo acérrimo y su respeto por la moral católica, la dictadura argentina no sostuvo una ideología muy elaborada. En ese sentido, se diferencia claramente de lo que se entendería por un régimen totalitario. La falta de reglas claras en lo que hace al ejercicio de la censura dio como resultado un campo cultural con múltiples instancias de negociación, en el que coexistieron fenómenos contradictorios. A mi juicio, la existencia de ese espacio irregular fue una de las condiciones para la emergencia de formas de subversión utópicas.

\section{El Ballet del San Martín}

El año 1968 constituye un momento fundacional para la historia de la danza contemporánea en Argentina, ya que se creó, bajo la dirección de Oscar Aráiz, el Ballet del Teatro San Martín, la primera compañía de danza contemporánea del país apoyada institucional y económicamente por el Estado. Hasta ese entonces, la danza contemporánea se había desarrollado a partir de iniciativas privadas y del trabajo de una organización no-gubernamental, la Asociación Amigos de la Danza, que funcionó entre 1962 y 1966 (Kaehler, 2012). Según lo relatado por Aráiz (1993: 8), en un texto que describe esta primera experiencia, el Ballet del Teatro San Martín heredó una identidad ligada a las obras que habían sido impulsadas por la Asociación Amigos de la Danza, cuya principal característica era la yuxtaposición de técnicas clásicas y modernas, generando una estética neoclásica que, podríamos decir, caracteriza hasta hoy en día la identidad estética de esa compañía.

A mediados de la década del 60, el campo de la danza contemporánea en Argentina era todavía incipiente. Los bailarines que integraron el Ballet en 1968 poseían diferentes formaciones. Un grupo ligado al Ballet del Teatro Argentino de La Plata, con bailarinas como Irma Baz o Norma Binaghi tenían una formación clásica; otro grupo integrado, entre otros, por Susana Ibáñez, Doris Petroni y Ana María Stekelman, poseían una formación contemporánea sólida; y un tercer grupo, que incluía a Mauricio Wainrot y José Carlos Campitelli, estaba compuesto por jóvenes que no tenían una gran experiencia. Todos estos bailarines son hoy en día personalidades del campo de la danza contemporánea argentina, lo cual muestra la importancia que tuvo esta primera formación en el desarrollo de la actividad artística en el país (Tambutti, 2000: 120). 
No obstante, la suerte del Ballet del Teatro San Martín en esos años estuvo fuertemente ligada al irregular arbitrio de las autoridades municipales. En 1968, César Magrini fue nombrado Director del Teatro, con el apoyo de Roberto Vernengo, Secretario Municipal de Cultura, y Manuel Iricibar, Intendente de la Ciudad de Buenos Aires. Magrini era un escritor y periodista, autor de las críticas musicales que se publicaban en el diario El Cronista Comercial. Desde ese medio, había realizado, en varias oportunidades, criticas muy elogiosas de las composiciones del, por entonces, joven coreógrafo Oscar Aráiz. Como relata el mismo Aráiz en una entrevista, el proyecto de creación del Ballet surgió de su propia iniciativa. Magrini lo convocó para organizar una serie de espectáculos de danza y el coreógrafo le propuso formar una compañía que trabajara en el teatro de manera permanente y que estuviera asociada a un lenguaje coreográfico contemporáneo (Isse Moyano, 2006: 112). Luego de un primer momento de hesitación, Magrini accedió a la propuesta.

En los años previos, el éxito de dos obras había impulsado el nombre de Aráiz para ocupar el rol de director del Ballet a pesar de su temprana edad, tenía veintisiete años en 1968. Una de ellas era la Consagración de la Primavera, estrenada en 1966 con el apoyo de la Asociación Amigos de la Danza, y la otra era Crash, estrenada en el Instituto Di Tella en 1967. Esta última obra significó un suceso inédito para la danza contemporánea en el país. Se representó en más de cien oportunidades durante 1967 y 1968, frente a un público promedio de más de ciento cincuenta espectadores, según indican los archivos contables del Instituto Di Tella. Recordemos que el Instituto Di Tella fue un centro de investigación cultural sin fines de lucro que funcionó en Buenos Aires entre 1958 y 1970. Durante los años 60 fue considerado un ícono de las vanguardias artísticas y de la contracultura argentinas. Su relación con el gobierno de facto de Juan Carlos Onganía fue sumamente tensa. Los espectáculos de danza funcionaron fundamentalmente en el marco de su Centro de Experimentación Audiovisual (CEA) (King, 2007).

Crash, presentada como un "divertimento en 1 acto y 22 cuadros sin telón" fue descripta por la crítica como un "experimento creativo", provocativo y humorístico (Revista Criterio 11 de abril de 1968). Crash, que contaba con una banda de sonido bastante ecléctica, que incluía desde el canto de una hinchada de fútbol hasta canciones de los Beatles, funcionaba como la expresión de una cultura juvenil emergente. En una nota periodística de la época, Aráiz afirmaba:

Hago cosas, siempre estoy haciendo cosas, no me detengo nunca porque detenerse es morir. Me apasionan las minifaldas y el pelo largo. El dinero no me entusiasma para nada: tengo un departamento en Belgrano, una cama, un perro - Ron - y tres cuadros. Eso es todo. En el Di Tella quise hacer un collage divertido, para salir un poco del ballet estereotipado, mostrar algo nuevo (Revista Siete días ilustrados 12 de diciembre de 1967: 42).

Las palabras de Aráiz, quizás un poco retocadas por el redactor de la nota, coincidían exactamente con los preconceptos básicos de la cultura hippie y del pop como movimiento artístico, ambas corrientes novedosas para la sociedad argentina en ese momento.

Dos años antes, la revista Primera Plana, por entonces el semanario más leído e influyente del país, publicaba una nota intitulada "Pop, ¿Una nueva manera de vivir?" ( ${ }^{\circ}$ 191, 23 de agosto de 1966: 70-75), en donde se ensayaba una definición de ese género artístico estableciendo como referencias a nivel nacional al Instituto Di Tella y a la artista Marta Minujín. La nota exponía, a modo de resumen del imaginario pop, una frase de la artista Susana Salgado: "No hacemos teoría, simplemente vivimos en un cuento de hadas" (75). El pop como movimiento cultural expresaba, supuestamente, 
una postura inconformista, pero, al mismo tiempo, naive con respecto a la realidad política y social. La nota de Primera Plana mencionaba, como un ejemplo de danza pop, la obra de las coreógrafas Marilú Marini y Ana Kamien, Dance Bouquet, presentada en el Di Tella en 1965, que puede pensarse como un antecedente estético de Crash. Ana Kamien es una coreógrafa con una intensa actividad artística en el terreno de la danza experimental entre los años 60 y 80. Junto a Marilú Marini tuvieron una presencia muy importante en el CEA perteneciente al Instituto Di Tella. (Isse Moyano, 2006:93-105).

Dance Bouquet incluía a artistas plásticos, músicos y actores, además de bailarinas y estaba inspirada en la cultura popular: los comics, las películas de Hollywood y el music-hall. De hecho, los gestos de las bailarinas provenían en muchos casos de fotografías de moda (Herrera, 2010: 42-43). Podríamos afirmar que, en el plano artístico, la figura de Oscar Aráiz al momento de la creación del Ballet del San Martín, se ubicaba en un lugar intermedio, y en cierto modo tenso, entre el movimiento pop, la cultura hippie y la alta cultura oficial representada, a nivel nacional, por el Teatro Colón.

Sin embargo, desde el punto de vista de la relación entre arte y política, la figura de Aráiz se ubicaba en un lugar diferente. El historiador y musicólogo Sergio Pujol identifica, en el espacio de la cultura juvenil de la época, una tensión entre dos vertientes: la del joven comprometido políticamente y la del joven de la contracultura asociado al rock, al pop y al movimiento hippie (2003: 311). A su juicio, existía en ese momento una incompatibilidad ideológica entre el "nacionalismo popular antiimperialista" característico de la Juventud Peronista y de los grupos políticos de izquierda, y las prácticas artísticas de la contracultura que eran vistas por los militantes políticos como una expresión del imperialismo cultural (2003: 313). Los artistas ligados a la contracultura se encontraban, de ese modo, frente a un doble rechazo, el primero por parte del gobierno de Onganía que asociaba sus prácticas a la subversión, y el segundo por parte de la militancia política de izquierda que los consideraba superficiales e imperialistas.

La nota de la revista Siete días ilustrados, que retrataba a Aráiz como a un hippie, era en realidad bastante crítica de la obra Crash. La interpretaba como una concesión comercial del coreógrafo luego del fracaso, que había significado la censura en 1967 de su obra Consagración de la Primavera. El artículo afirmaba:

[...] cuando este año la censura objetó la representación de la Consagración de la Primavera de Igor Stravinsky en el Teatro Colón, por considerar que obra y coreografía atentaban contra las buenas costumbres. Aráiz no sólo perdió parte de su público. Fundamentalmente, quedó fuera del marco de prestigio oficial que envuelve al viejo edificio de la calle Libertad [el Teatro Colón]. Decidió entonces presentarse en otro edificio cultural, menos prestigioso y oficial, [...] el Instituto Di Tella (Revista Siete días ilustrados 12 de diciembre de 1967, 42).

Para el autor de la nota, Crash era una desesperada tentativa por ubicarse o adecuarse a ese nuevo ambiente artístico, luego del rechazo recibido por parte de la cultura oficial. La lectura periodística, que en cierto modo culpabilizaba a Aráiz de la censura que su obra había sufrido, no era ingenua. En realidad, se proponía legitimar implícitamente, circunscribiéndola a criterios supuestamente estéticos, la política de control cultural que el gobierno autoritario de Onganía venía ejerciendo.

\section{La censura}

Como afirma Buch (2001: 109-110), desde el golpe de Estado del 28 de junio de 1966, el gobierno autoritario llevó adelante una campaña de moralización de la vida pública 
destinada a censurar prácticas individuales como, por ejemplo, llevar el pelo largo, besarse en las plazas, tener relaciones extraconyugales o ser homosexual. A la prohibición de los partidos políticos se sumó una intervención constante en la vida cultural, lo cual se hizo manifiesto en la censura de múltiples formas de expresión: gráfica, artística, cinematográfica, teatral, musical y dancística. La política de censura ocupó un lugar central en el esquema de gobierno impulsada directamente por la esposa del dictador, María Green de Onganía. Fue ella quien abandonó el Teatro Colón escandalizada frente a la supuestamente exacerbada carga erótica de La consagración de la primavera de Oscar Aráiz. Era el 17 de mayo de 1967 y la coreografía estaba siendo presentada en el marco de una velada en homenaje al príncipe Akihito de Japón. La reacción de la esposa de Onganía significó que la obra fuese inmediatamente excluida de la programación del teatro.

A los dos meses, el 9 de julio de ese mismo año, y con el antecedente escandaloso de la obra de Aráiz, Onganía exigió terminantemente la prohibición de la ópera Bomarzo de Alberto Ginastera y Manuel Mujica Láinez, en la cual también participaba Aráiz como coreógrafo. El compositor Alberto Ginastera era a su vez Director del Centro Latinoamericano de Altos Estudios Musicales (CLAEM) perteneciente al Instituto Di Tella. La censura de Bomarzo dificultó su capacidad de obtener subsidios necesarios para el funcionamiento del centro.

El caso Bomarzo, estudiado por Buch (2003), desnudó las incongruencias de la política cultural del gobierno militar y generó una respuesta fuerte por parte de la prensa. La ópera se había estrenado en el Lisner Auditorium de la ciudad de Washington el 19 de mayo de ese mismo año, frente a un público que había incluido al vicepresidente de EEUU y al embajador argentino. Mediante un decreto oficial del mes de abril, el gobierno había declarado que su estreno constituía un importante acontecimiento para la cultura argentina. Resultaba inverosímil que la misma obra fuese censurada, a menos de un mes de diferencia, debido a su "referencia obsesiva al sexo, la violencia y la alucinación" (Revista Criterio n ${ }^{\circ}$ 1529, 10 de agosto de 1967, 564).

La censura de la ópera Bomarzo, al igual que la de la Consagración de Aráiz, exponía las tensiones internas que acosaban al gobierno dictatorial. Como afirma Sidicaro (2004: 81), ninguna otra coalición golpista integró actores tan opuestos con intereses y visiones de la realidad social tan disímiles como la que llevó a Onganía al poder en 1966. La política moralizadora del gobierno respondía a la influencia de la Iglesia Católica, la que a su vez se contraponía a cierta parte de la burguesía culturalmente sofisticada y también cercana al gobierno, que veía en obras como Bomarzo o la Consagración de la Primavera, una expresión de modernidad cultural. Esta falta de homogeneidad en la apreciación de las prácticas artísticas se conjugaba con una implementación de la censura de manera poco clara y, en cierto modo, perversa.

A diferencia de otros casos ejemplares, como por ejemplo el de la España franquista, en la Argentina nunca hubo una oficina de censura centralizada, con prácticas establecidas y con una organización administrativa visible (Avellaneda, 1986:13-14). Excepto en los casos del cine o la radio, el discurso de la censura tampoco estipuló códigos precisos, por fuera de ciertos lineamientos morales generales opuestos a la ideología comunista. Esta indeterminación se propuso establecer mecanismos de autocensura, tanto por parte de los artistas como por parte de las instituciones culturales que eran responsables por las obras que presentaban. La nota de la revista Primera Plana, "La censura va por dentro" daba cuenta de esta situación ( ${ }^{\circ} 282,21$ de mayo de 1968 , 74). De hecho, la revista Primera Plana también es censurada entre noviembre de 1969 y septiembre de 1970. Durante ese tiempo, los periodistas de la revista publican un semanario con el titulo Periscopio. 
Las autoridades asumían, a su vez, un doble discurso que relativizaba sus propios actos de censura. En una entrevista reciente, Oscar Aráiz afirmaba que en realidad nunca se publicó un decreto que prohibiera su obra Consagración de la Primavera (Entrevista realizada a Oscar Aráiz por el autor de este artículo el 27 de marzo de 2014). Se la excluyó del Teatro Colón, pero no se prohibió expresamente su representación en otros teatros. Un procedimiento similar se produjo con la ópera Bomarzo, como afirma Buch (2003: 109). Es necesario aclarar que esta estrategia no era improvisada o ingenua, como la presentaban los medios gráficos. Lo que se buscaba era imponer una autocensura sin verse en la necesidad de publicar un decreto oficial. El gobierno autoritario tenía autoridad para volver a censurar la presentación de las obras en cualquier momento y en cualquier teatro, con lo cual era muy poco probable que un productor privado invirtiera su dinero en la obra o decidiera programarla luego de ese antecedente. De hecho, fue eso lo que ocurrió. La Consagración de Aráiz volvió a representarse recién en 1970, luego de que Onganía dejara de ocupar el rol de presidente de facto y su poder político mermara.

\section{La Consagración de la Primavera}

Como sostiene Fortuna (2013: 64), la referencia a las metrópolis culturales, en el caso de la danza, funcionó históricamente como un modo de legitimación de la producción artística vernácula. La Consagración de la Primavera de Aráiz reprodujo en cierto modo esta lógica. El hecho de que un coreógrafo argentino estuviera en condiciones de producir una versión de una obra canónica, acercaba o pretendía acercar a la Argentina, simbólicamente, al nivel cultural de Europa y EEUU. La nota que se publicó en la revista Panorama, a propósito del estreno en 1966, intitulada "La consagración de Stravinsky y sus coreógrafos", confirma esta interpretación. El artículo señalaba con orgullo a Aráiz como el sexto coreógrafo -luego de Vaslav Nijinsky, Leonide Massine, Boris Romanoff, Maurice Béjart y Kenneth MacMillan- en crear un ballet basado en la música de Stravinsky (Panorama ${ }^{\circ} 39$, Agosto de 1966, 5). En base a este discurso, se puede entender por qué el canciller argentino eligió agasajar al príncipe de Japón con una representación de esta obra. El objetivo sería demostrar el alto nivel cultural del país.

No obstante, el crítico de la revista Panorama subrayaba la gran influencia que presumiblemente había ejercido Maurice Béjart en la versión de Aráiz. El coreógrafo francés había presentado su Consagración en el Teatro Colón, en 1963, generando un impacto muy positivo en el público y en el campo artístico locales. La nota daba a entender que la versión de Aráiz era una especie de copia de la Consagración de Béjart. El carácter incompleto del "proceso de modernización" de la danza argentina (Fortuna, 2013; García Canclini, 2005) quedaba expuesto en el caso de esta obra, a través de su supuesta falta de originalidad. Cabe preguntarse si esto habla de la voluntad del coreógrafo argentino de adoptar una referencia extranjera que legitime sus ideas estéticas o de una lectura colonialista por parte de la crítica. Al menospreciar sutilmente el trabajo de Aráiz por su falta de originalidad, el crítico se coloca a sí mismo como un agente reproductor del colonialismo estético. Desde esta lógica, es el crítico, y no el coreógrafo, el actor capaz de acceder a un conocimiento universal y válido de la danza contemporánea. Desde su lugar de saber, el crítico señala la falta del artista local. Se genera así una situación paradójica a partir de la cual el crítico periférico legitima su lugar de poder a través de la confirmación del carácter periférico de la cultura local. No pretendo aquí defender la originalidad del trabajo de Aráiz, una condición que, por lo que tengo entendido, tampoco interesa demasiado al coreógrafo. En todo caso, considero que el lugar de la crítica no debería ser el de legislar acerca de la originalidad de una propuesta escénica, sino el de exponer su valor estético, político y sensible en el contexto de su emergencia y representación. El trabajo no 
se limita a concebir la arquitectura interna de la obra como una abstracción estética exclusivamente, sino que implica ponderar lo que la obra viene a decir y lo que hace, en un lugar y en un momento determinados.
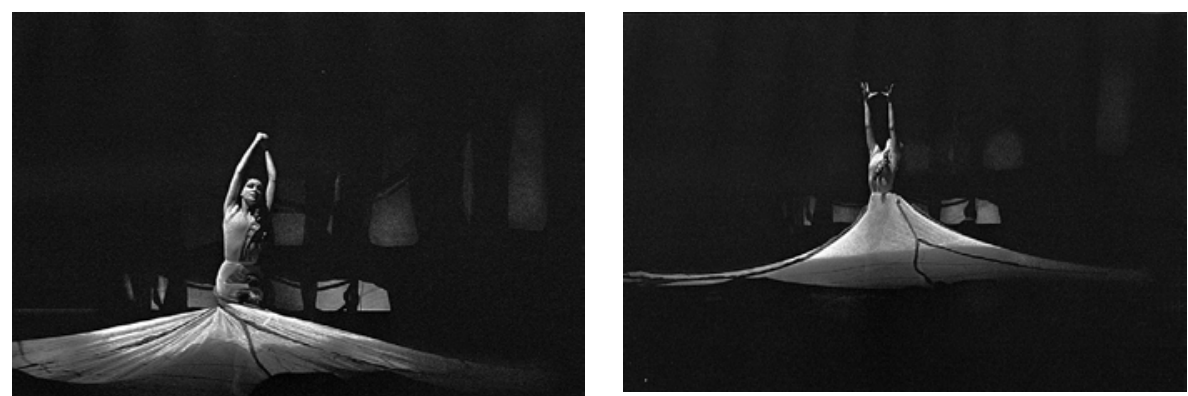

Consagración de la Primavera (Aráiz, 1970). Fotos de Alicia Sanguinetti.

Oscar Aráiz tenía veintiseis años en el momento del estreno de su Consagración. En una entrevista (Falcoff, 2008: 270), afirma que su interés por la música de Stravinsky se remonta a su infancia y al comienzo de sus estudios de danza con Elide Locardi, una de las llamadas pioneras de la danza moderna en Argentina (Osswald, 2010: 45). Lo que más impactó a la crítica periodística de la época, entre ellos, a César Magrini, quien dos años más tarde haría posible la creación del Ballet del Teatro San Martín, fue el cuadro inicial de la obra, intitulado Germinación. Aráiz lo describe en una entrevista de la siguiente manera:

es el espíritu de la tierra que despierta. Hay una mujer o puede ser un hombre que cubre todo el escenario con una pollera, toda la tela está tirante y esa mujer está volcada, es como un brote, algo que empieza a germinar, que sale de la tierra, un tallo. Abajo la tierra se empieza a enroscar y se convierte en una placenta monstruosa, los bailarines que están debajo forman bolsas con la respiración y todo eso comienza a tomar vida. Poco a poco se va dando a luz toda esa sociedad, a esa tribu que va a generar el ritual (Entrevista realizada a Oscar Aráiz en 1990, por Clara Beatriz Kriger y Francisco José García para un texto inédito que se encuentra en los archivos del Centro de Documentación de Teatro y Danza del Complejo Teatral de Buenos Aires)

La obra representaba una idea de regeneración, el nacimiento de una nueva sociedad, un anhelo que existía claramente en ese entonces, sobre todo entre los jóvenes. A lo largo de los años, Aráiz realizó numerosas declaraciones acerca de esta obra, que, según su opinión, cambió profundamente su significado en función de las diferentes versiones en las que fue presentada. Brigitte Kehrer (1988: 17) describe la versión que el coreógrafo realizó en Ginebra en 1982, durante la guerra de Malvinas, a la que le impuso un carácter agresivo y militar, modificando la escenografía, como un modo de expresar su angustia ante el enfrentamiento bélico entre Argentina y Gran Bretaña. Retrospectivamente, Aráiz define la versión de los años 60 de Consagración... como una "fiesta dionisíaca" que lo llevó a ser contratado para coreografiar todas las bacanales operísticas del Teatro Colón de esos años como Sansón y Dalila, Bomarzo, Moisés y Aaron, y Padmavati (Isse Moyano, 2006: 112). La carga erótica de la obra no era un elemento ajeno a la voluntad de su creador y, en cierto modo, formaba parte de su proyecto estético en aquel momento.

El mismo año de la creación del Ballet del Teatro San Martín, aconteció el suicidio de la coreógrafa alemana Dore Hoyer. Oscar Aráiz había formado parte de una compañía dirigida por Hoyer en el Teatro Argentino de La Plata, durante 1960. A modo de homenaje, Aráiz realizó una recreación de la obra Cadena de fugas que se presentó ese mismo año, en 1968. Como un modo de contrastar con el clima introspectivo de la 
obra de Hoyer, Aráiz presentó al mismo tiempo Beat Suite, un divertimento que representaba una continuación de la estética pop de Crash. 1968 fue un año positivo para el Ballet, pero terminó con un cambio de autoridades en la Municipalidad de Buenos Aires. Se nombró a Alberto Obligado como Secretario de Cultura y, al año siguiente, la Dirección General del teatro fue asumida por Fernando Lanús. El nombramiento no perjudicó necesariamente al grupo, ambos funcionarios hicieron posible, en septiembre de 1969, la primera gira europea de la compañía que visitó París, Londres y Madrid. Sin embargo, el tercer año sería bastante difícil. En palabras de Aráiz:

1970 sería el último de esos tres significativos años del Ballet del Teatro San Martín; aunque el plantel no sufrió grandes modificaciones, casi toda la temporada estuvo oscurecida por las amenazas, los presagios, los temores, los rumores, la censura y peor aún, la autocensura (1993: 16).

Ese mismo año, el Ballet del Teatro San Martín repuso la obra Consagración de la Primavera, que había sido censurada por pedido de Onganía tres años antes. El dictador había sido reemplazado por Roberto Marcelo Levingston, pero la tensión alrededor del reestreno de la obra se mantuvo. Aráiz afirma haber tenido que realizar un ensayo general frente a las autoridades del teatro antes de la presentación, a los fines de obtener su aprobación antes del estreno $(1993,16)$. En un artículo de la revista Primera Plana intitulado "Consagraciones y Brujerías", publicado dos años después de esa presentación, el autor anónimo de la nota realizaba una suerte de descripción histórica de los avatares que había sufrido la obra. Comenzaba relatando el escándalo acontecido durante el agasajo al príncipe de Japón en 1967 y luego afirmaba que, en 1970, la obra había podido reponerse gracias a que Aráiz había prometido realizar importantes modificaciones en la coreografía y en los trajes (Primera Plana, $\mathrm{n}^{\circ} 481,18$ de junio de 1972, 52). Según el autor de la nota, a pesar de esas promesas, la obra se había presentado del mismo modo que en las anteriores ocasiones. La única variante fundamental había sido el cambio del protagonista masculino que, en ese caso, fue el bailarín Freddy Romero. Por esta razón, puede interpretarse que, al menos para cierta parte de la prensa, Consagración de la primavera era una obra disruptiva y su reposición, una forma de resistencia al poder autoritario en el plano cultural.

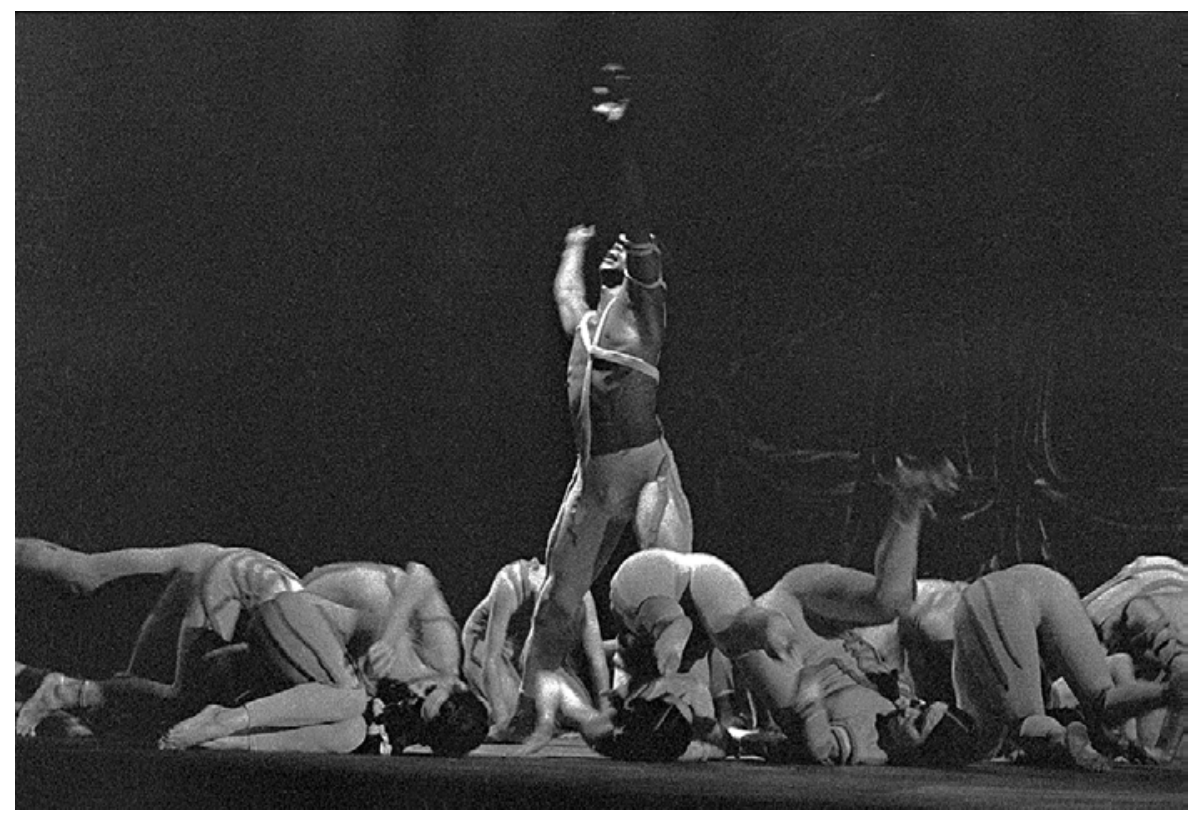

Consagración de la Primavera (Aráiz, 1970). Foto de Alicia Sanguinetti. 
En su versión de 1970, el programa de Consagración de la Primavera presentaba un texto compuesto a partir de citas extraídas del libro de Georges Gusdorf (1960), Mito y Metafísica, que decía:

La fiesta aparece como una liturgia global, como un fenómeno total [...] la existencia toda se transfigura. La fiesta es el gran juego social de la trascendencia, el recomenzar del Gran Comienzo. El universo se halla en tren de nacer, y [...] restituye a los humanos las inmensas posibilidades perdidas. La fiesta restablece la situación límite donde el orden ha nacido del desorden, donde caos y cosmos se hallan todavía contiguos. [...] las individualidades pierden su distancia y tienden a confundirse. [...] La fiesta se constituye como una representación sin público. Todo el mundo representa para todo el mundo. La fiesta celebra la alegría del hombre, la juventud del mundo y la juventud del hombre (1960: 76-85).

Varias de las ideas presentes en esta cita resuenan en la obra de Aráiz, en la cual la fiesta expresa una utopía de cambio y regeneración. Según pude constatar a través de diversas entrevistas con Aráiz y con varios espectadores e intérpretes, la coreografía mantuvo su estructura a lo largo del tiempo. Ante la inexistencia de un registro fílmico de las presentaciones de 1967 y 1970, mis referencias son las entrevistas citadas y la única versión filmada a la que se puede acceder en el Centro de Documentación de Teatro y Danza del Complejo Teatral de Buenos Aires, que data de los años 90. La Consagración de Aráiz respeta los lineamientos básicos de la obra original de Nijinski: la existencia de un grupo tribal, la división de los intérpretes por género (masculino y femenino) y la centralidad del personaje de la elegida hacia el final de la obra. En su desarrollo, se presentan varias escenas de dúos hombre-mujer de estilo erótico. Los cuerpos se rozan, se revuelcan, se someten y reproducen movimientos que remiten al acto sexual humano o al apareamiento animal. La obra expresa en este sentido cierta fusión del cuerpo humano con la naturaleza, unido por un instinto básico ligado a la reproducción. Sin embargo, los dos momentos que considero más impactantes son el principio y el final de la obra.

En la primera escena, Germinación, un personaje cubre todo el escenario con una pollera y su torso emerge como el tallo de una planta que sale de la tierra. Esa tierra es representada por una masa humana de cuerpos que se entrelazan y confunden entre sí, actuando como un cuerpo único. El vestuario compuesto por mallas color piel da a su vez la impresión de un cuerpo desnudo con un sexo neutro. En la escena final de la muerte de la elegida se repite esta estructura compuesta por una masa informe de cuerpos. En lugar de bailar hasta la muerte, como en la versión de Nijinski, la elegida trepa a una montaña de cuerpos formada por los bailarines y se eleva por encima del grupo. En la versión de los años 90, la elegida queda suspendida en el aire, sostenida por una soga que cuelga del techo, pero, en la versión de 1970, como cuenta José Carlos Campitelli que fue uno de los intérpretes, el personaje de la elegida, interpretado por Ana María Stekelman, llega a la cima y se deja caer de espaldas hacia el público.

La idea de fiesta, propuesta por Gusdorf y citada por Aráiz, es presentada por esa masa informe de cuerpos que inauguran y culminan la representación. En sus términos, podríamos afirmar que se trata de la manifestación utópica de una revolución total. El teórico de los estudios de performance José Esteban Muñoz (2009) desarrolla una reflexión a propósito de lo utópico inspirada en la filosofía de Ernst Bloch. El arte, desde una aproximación blochiana, es capaz de expresar una iluminación anticipatoria que, según Muñoz (2009: 3), nos ayuda a ver aquello que aún no es consciente bajo la forma de un "sentimiento utópico". En el mismo sentido, Muñoz hace referencia a la diferenciación hecha por Agamben (1999) entre posibilidad y potencialidad: 
unlike a possibility, a thing that simply might happen, a potentiality is a certain mode of nonbeing that is eminent, a thing that is present but not actually existing in the present tense

[a diferencia de una posibilidad, algo que simplemente podría suceder, una potencialidad es un cierto modo de no ser que se destaca, algo que está presente pero que no existe realmente en el tiempo presente] (2009: 9).

Consagración presenta, en las escenas citadas, una fusión de cuerpos cuasi desnudos con géneros imprecisos que proyectan un sentimiento utópico de comunidad sin jerarquías. La obra anuncia la potencialidad de una refundación de la sociedad, a partir de la vuelta a un estado de desindividuación, de identificación mecánica con el otro.

Aquí la sexualidad no se hace presente como identidad individualizante, sino como práctica relacional, como el camino hacia una armonía colectiva. Aquello que los militares y los moralistas católicos rechazaban como un acto de perversión e impudicia, expresaba la utopía de una solidaridad amorosa entre los cuerpos. La masa humana que se hace presente en la obra de Aráiz puede asociarse a los relatos sobre prácticas de sexo colectivo escritos por Samuel Delany y citados por José Esteban Muñoz, en los cuales los seres humanos "took care of one another not only by offering flesh but by performing a care for the self that encompassed a vast care for others - a delicate and loving 'being for others' [se cuidaban mutuamente no sólo ofreciendo sus cuerpos, sino también realizando un cuidado de sí mismos que abarcaba un vasto cuidado de los demás, un delicado y amoroso 'ser para los demás']" (Muñoz, 2009: 51). Es este "ser para los demás" lo que representa el lazo primordial de la revolución utópica planteada por Consagración. La obra de Aráiz apunta a una colectividad futura, a la potencialidad de una sociedad orgiástica como horizonte presente. Es este un sentimiento utópico que, intuimos, deambula por el imaginario de la cultura juvenil argentina de la época. Como señala Jill Dolan (2005: 7), el arte constituye un espacio en el que puede expresarse "otro mundo", no de un modo didáctico o descriptivo sino a través de la posibilidad de vivir una experiencia alternativa. La obra expone al espectador a la experiencia de una comunidad utópica y esto constituye, en el plano sensible, un acto de subversión frente a un poder autoritario represivo, aterrador e individualizante.

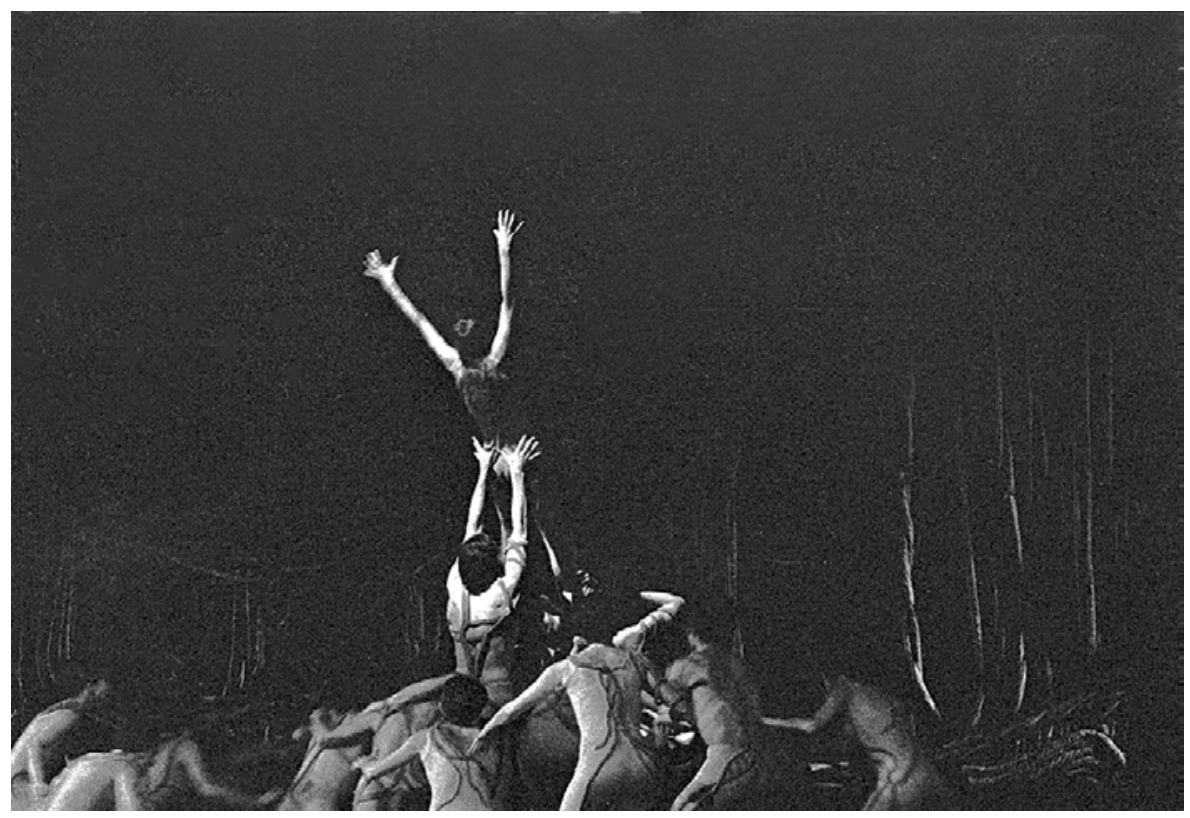

Consagración de la Primavera (Aráiz, 1970). Foto de Alicia Sanguinetti. 


\section{Fedra}

Algunos meses antes del reestreno de la obra de Aráiz, se había presentado otra obra que también había generado intentos de censura por parte de las autoridades del teatro. Se trataba de la obra Fedra de la coreógrafa chilena Ana Itelman, basada en textos de Eurípides, Racine y Unamuno. A pesar de que su trabajo no haya tenido el reconocimiento oficial que obtuvo el de Oscar Aráiz, Ana Itelman representa hasta hoy en día una referencia muy importante para varias generaciones de bailarines y coreógrafos argentinos. Fue profesora del Taller de danza del Teatro San Martín, cuyas actividades comenzaron en 1977, y estuvo en contacto permanente con el Ballet del teatro hasta su trágica muerte en 1989. Itelman había formado parte de la compañía de danza moderna creada por Miriam Winslow en Argentina durante el año 1944. Su contacto con la danza norteamericana se afianzó en los años siguientes ya que viajó a EEUU en 1945 y tomó clases con Martha Graham, Louis Horst, Hanya Holm y José Limón.

En los años 50, volvió a la Argentina y, luego de sufrir una enfermedad que le impidió continuar su carrera como bailarina, fundó una escuela de danza y se desempeñó como coreógrafa. En 1957, retornó a EEUU, donde trabajó durante doce años como profesora asociada y luego directora del departamento de danza del Bard College de Nueva York. En esos años presentó obras como House of Doors, Jove and Io, Three Rivers, There is a Dead Horse in the Bathtub and other Perplexities, The Girl in the Black Raincoat o The Man with the Blue Guitar (Szuchmacher, 2002: 19-20). Más allá de su intensa actividad en EEUU, Itelman volvía regularmente a la Argentina para presentar obras con el apoyo de la Asociación Amigos de la Danza y del Ballet del Teatro San Martín. Se reinstaló en Buenos Aires en 1969 y fundó un Café Estudio de Teatro Danza, establecimiento que más tarde fue donado al teatro. El Taller de Danza Contemporánea del Teatro San Martín funciona en ese lugar hasta la actualidad. Entre sus obras más famosas, presentadas en Argentina, figuran Casa de Puertas, Ciudad nuestra Buenos Aires, Odi et Amo, Dobletres, Las Casas de Colomba, Historia del Soldado, Suite de Percal, 20x12+1 Fuga, Y ella lo visitaba y El Capote. Ana Itelman constituye una referencia insoslayable en el terreno de la Danza Teatro en Argentina. Luego de la muerte de la coreógrafa, el Archivo Itelman, en donde se encuentran cuadernos con anotaciones, dibujos y diversas notas referidas a sus obras, fue donado al Centro de Documentación de Teatro y Danza del Complejo Teatral de Buenos Aires. Ahora bien, el año que marca el punto de tensión más alto entre la compañía y las autoridades del Teatro San Martín es 1970. El intento de censura de la obra Fedra, sin duda, profundizó el enfrentamiento. Según indica Rubén Szuchmacher ${ }^{2}$ (2002: 151), la razón de la censura, se debería a que, luego del preestreno para críticos y autoridades, la mujer de un alto funcionario habría hecho un escándalo a su marido pidiéndole que prohibiera la obra debido a la obscenidad de ciertas escenas. Quedaba expuesta, una vez más, la supuesta inmoralidad de la danza, al menos a los ojos de la élite militar en el poder. En cuanto al contenido de la obra, de la cual no se conserva ningún archivo fílmico, el programa, escrito por Ana Itelman, decía lo siguiente: "Fedra, montaje escénico para ser filmado. Fedra se mueve en medio de una sociedad implacable que la obliga a vivir y morir precariamente. La anécdota es simple; cuenta el amor de una mujer madura por su hijastro, Hipólito".

2 Rubén Szuchmacher comenzó su relación con Ana Itelman como alumno y terminó siendo su colaborador en los últimos años de su vida. En 1992 ganó una beca de la Fundación Antorchas para hacer una investigación sobre la coreógrafa que quedó plasmada en el libro Archivo Itelman (Szuchmacher 2002). 


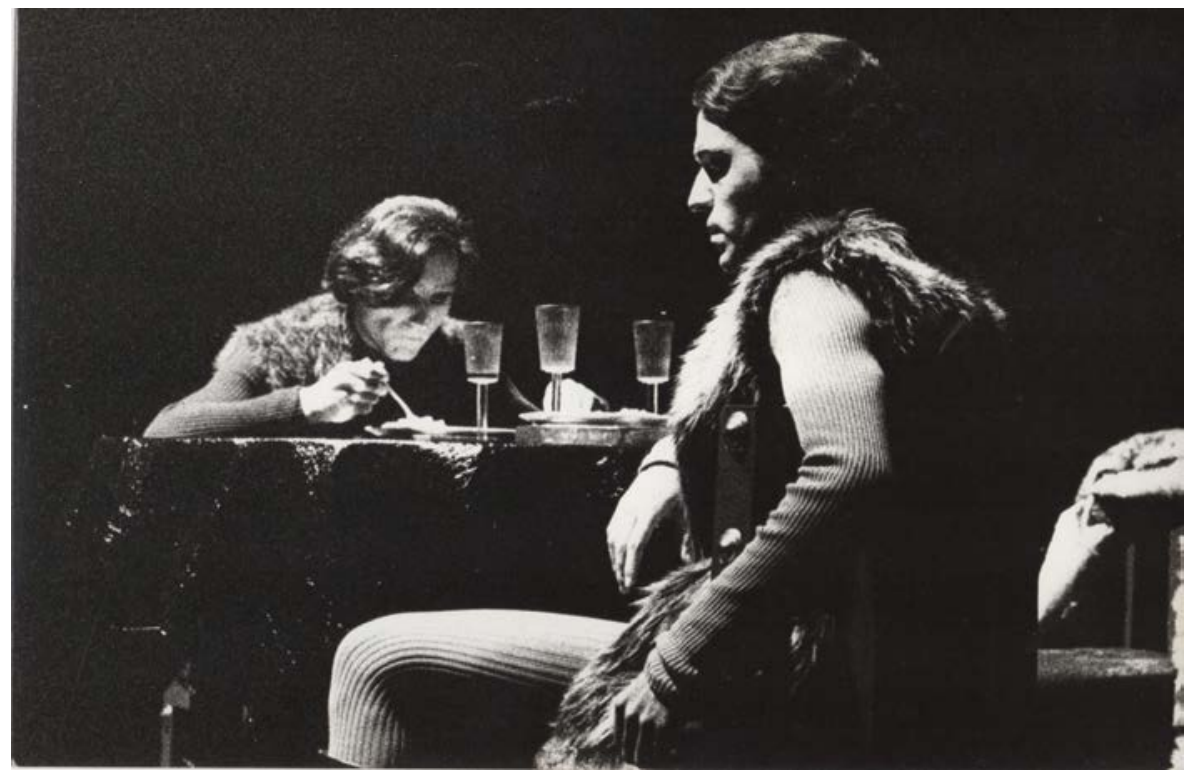

Fedra (Itelman, 1970). Foto de Hector Boetto. Gentileza de José Carlos Campitelli.

Según lo afirmado en entrevistas por José Carlos Campitelli, que interpretaba el papel de Hipólito, el proceso de creación fue muy difícil (Entrevista realizada por el autor de este articulo a José Carlos Campitelli el 26 de agosto de 2015). Los ensayos duraron ocho meses y se proponían desarrollar capacidades actorales en bailarines que no habían recibido ese tipo de formación. En el programa, Ana Itelman incluyó el siguiente texto que daba cuenta del proceso de creación:

En noviembre de 1969 los integrantes del Ballet del San Martín que componen el elenco de Fedra, comenzaron los ensayos. En principio, el planteo exigió por parte de la autora, un esquema y dirección. Más adelante la obra se trabajó por medio de los temas propuestos y la dirección se transformó en observación y captación del material ganado en las improvisaciones. A medida que el grupo adquirió confianza y se interiorizó del sentido profundo de Fedra, pudo -cada vez más-, prescindir de la Dirección. Esta fase final representa a mi juicio, el más importante resultado de este cúmulo de experiencias. El grupo puede interpretar la obra, en la medida en que la vive en escena, porque cada uno se adentra en su personaje a través de su propia individualidad. Los actores-bailarines entran a un set donde se filman escenas de Fedra. La obra no tiene principio ni fin. Son escenas aisladas las que podrán montar como el espectador más lo desee. A. I.

Fedra fue pensada como una fotonovela, no incluía escenas de danza y estuvo fundamentalmente basada en improvisaciones. En base a archivos fotográficos y al testimonio de José Carlos Campitelli y de Doris Petroni, podríamos afirmar que la obra presentaba numerosas escenas de contacto físico entre los intérpretes. Existía una escena, relatada por Doris Petroni (el relato tuvo lugar durante una entrevista a Doris Petroni realizada por el autor de este artículo el 17 de septiembre de 2015), que interpretaba el personaje de Fedra, en la que ella se sentaba en la falda de Hipólito, lo acariciaba e intentaba besarlo ante la presencia del personaje de Enrique, su esposo, interpretado por Enrique Zabala, que fingía no observar nada de lo que sucedía. José Carlos Campitelli recuerda igualmente, una escena que le causaba mucho pudor en la que él se bañaba semidesnudo en escena. Fue una obra que, según el relato de Campitelli, marcó mucho a los intérpretes. Se vivía una atmósfera muy tensa durante los ensayos, ya que Ana Itelman había adoptado una actitud muy compulsiva con respecto a la puesta en escena. Aráiz, desde su lugar de director del 
Ballet, afirmó que el proceso de creación de la obra fue "inquietante, oscuro, con propuestas novedosas y [que], como en toda aventura auténtica, la angustia [los] mantenía en suspenso" (Aráiz 1993, 16). Desde un punto de vista artístico, podría decirse que la obra representó una experiencia de vanguardia para la danza contemporánea en Argentina.

La supuesta obscenidad que justificaba la censura estaba dada fundamentalmente por la representación escénica del deseo de una mujer madura por un hombre joven, algo que desafiaba la cultura patriarcal de ese entonces. El mito representaba una historia en la que se invertía la dinámica de roles del cortejo amoroso y se oponía el deseo femenino al mandato maternal. Fedra ponía en escena una forma de feminidad novedosa, que expresaba, en cierto modo, el avance de la mujer en una sociedad argentina, aún atada a modos de vida conservadores y permeables a la moral católica, más allá de las diversas convicciones político partidarias. Como señala Felitti (2012: 12), el hecho de privilegiar la procreación y el carácter maternal de la mujer por sobre su libertad individual es en la época una idea sostenida tanto por los conservadores como por los grupos ligados a la militancia política de izquierda. Sin embargo, los cambios en la subjetividad femenina eran parte del proceso de contestación social generalizado que se estaba gestando. En 1966, el sociólogo argentino Julio Mafud publicaba un libro de investigación sociológica intitulado La revolución sexual argentina en donde se describían, fundamentalmente, los cambios en la sexualidad femenina y la aparición de nuevas prácticas amorosas luego de la introducción de la píldora anticonceptiva y del ingreso de la mujer en el mercado laboral. Mafud definía este fenómeno como una "revolución sexual" que indicaba "el cambio más profundo que se [hubiera] producido en la sociedad argentina moderna" (Mafud, 1966: 11).

En última medida, Fedra subvierte la figura del macho dominante que según Taylor (1997: 17) constituye un eje central de la construcción del Estado nación argentino. Es innegable que la obra de Itelman toca una fibra sensible que desestabiliza la figura de la virilidad masculina claramente asociada al arquetipo del hombre militar como líder (1997: 38). En este sentido, la obra desafía abiertamente la "feminización del enemigo" (1997: 62) y la construcción de la identidad nacional a partir de la "destrucción de lo femenino" (1997: 9) estudiadas por Taylor. La subversión en este caso implica la inversión del sentido de una dominación.

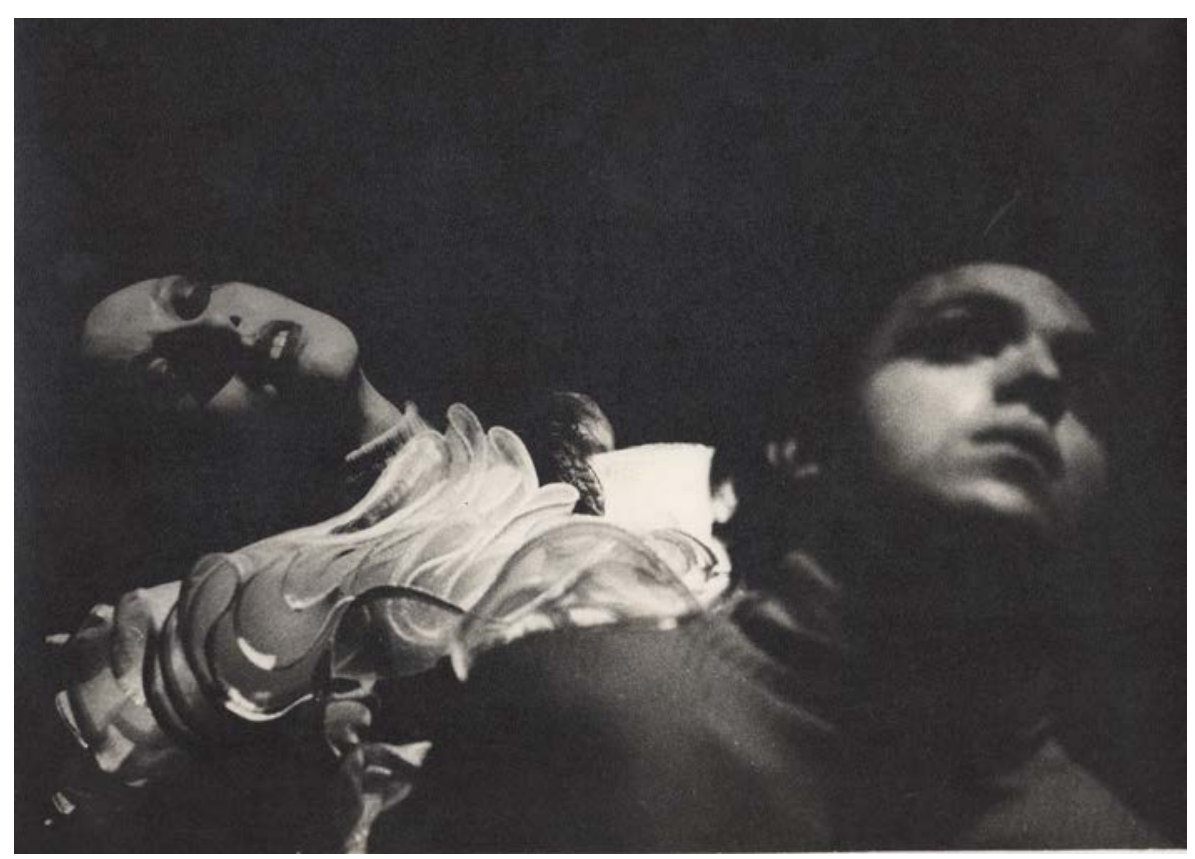

Fedra (Itelman, 1970) - Foto de Norberto Lavecchia - Gentileza de José Carlos Campitelli 
Dolan utiliza el concepto de "performances utópicas" y lo define como

small but profound moments in which performance calls the attention of the audience in a way that lifts everyone slightly above the present, into a hopeful feeling of what the world might be like if every moment of our lives were as emotionally voluminous, generous, aesthetically striking, and intersubjectively intense [momentos pequeños pero profundos en los que una actuación llama la atención de la audiencia de una manera que eleva a todos ligeramente por encima del momento actual, en un sentimiento esperanzador de cómo sería el mundo si cada momento de nuestras vidas fuera tan emocionalmente voluminoso, generoso, estéticamente impactante, e intersubjetivamente intenso] (Dolan, 1997: 5).

El concepto se asocia, según Dolan, a la noción de gestus del director de teatro Bertolt Brecht definida como acciones performáticas que cristalizan relaciones sociales y las ofrecen a los espectadores para una contemplación crítica (1997: 7). En su escenificación del deseo femenino, un deseo que avasalla las instituciones del matrimonio y de la familia, Itelman expone una realidad social subversiva. Las escenas de Fedra representan la utopía de una dominación femenina guiada por el deseo y el placer en contraposición con un contexto claramente dominado por lo opuesto: lo masculino, el autocontrol y la represión.

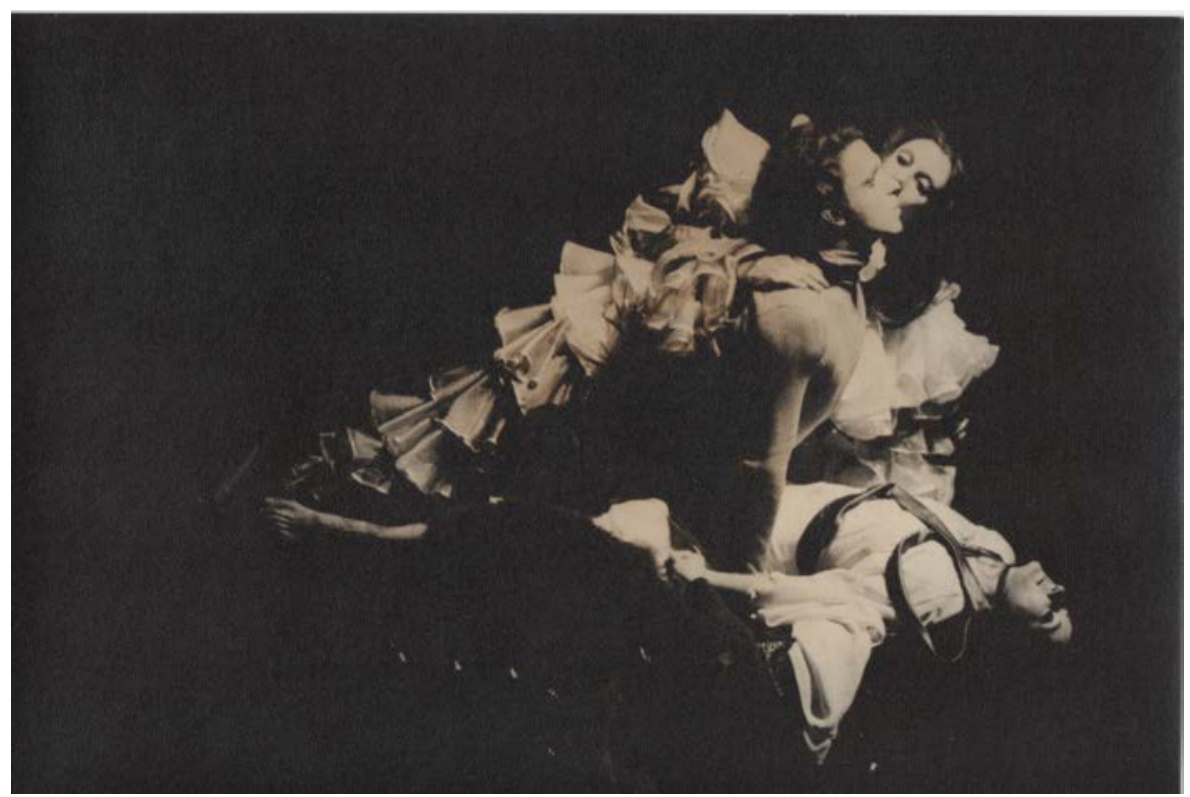

Fedra (Itelman, 1970). Foto de Norberto Lavecchia. Gentileza de José Carlos Campitelli.

En un texto de 1983, el poeta y sociólogo Néstor Perlongher (2008: 25-27) recuerda los edictos policiales que se usaban durante la dictadura para controlar el cuerpo femenino en lo referido al uso de minifaldas o la interacción con personas del sexo opuesto o del mismo sexo en el espacio público. Fedra se diferencia de las reivindicaciones feministas de la época. No se trata sólo de afirmar la potestad de la mujer sobre su propio cuerpo, sino que afirma el deseo cuasi-perverso de una mujer oprimida. En este sentido, su propuesta se asocia a las ideas político-sexuales radicales de Perlongher expresadas en su frase: los homosexuales "no queremos [...] que nos toleren, ni que nos comprendan: lo que queremos es que nos deseen" (Perlongher, 2008: 34). Del mismo modo en que los homosexuales, según Perlongher, quieren ser deseados, las mujeres, representadas por Fedra, quieren desear, quieren ejercer un rol activo, quieren dominar. Es un gesto de subversión utópica que busca desestabilizar la dominación masculina proyectando una potencialidad matriarcal. 


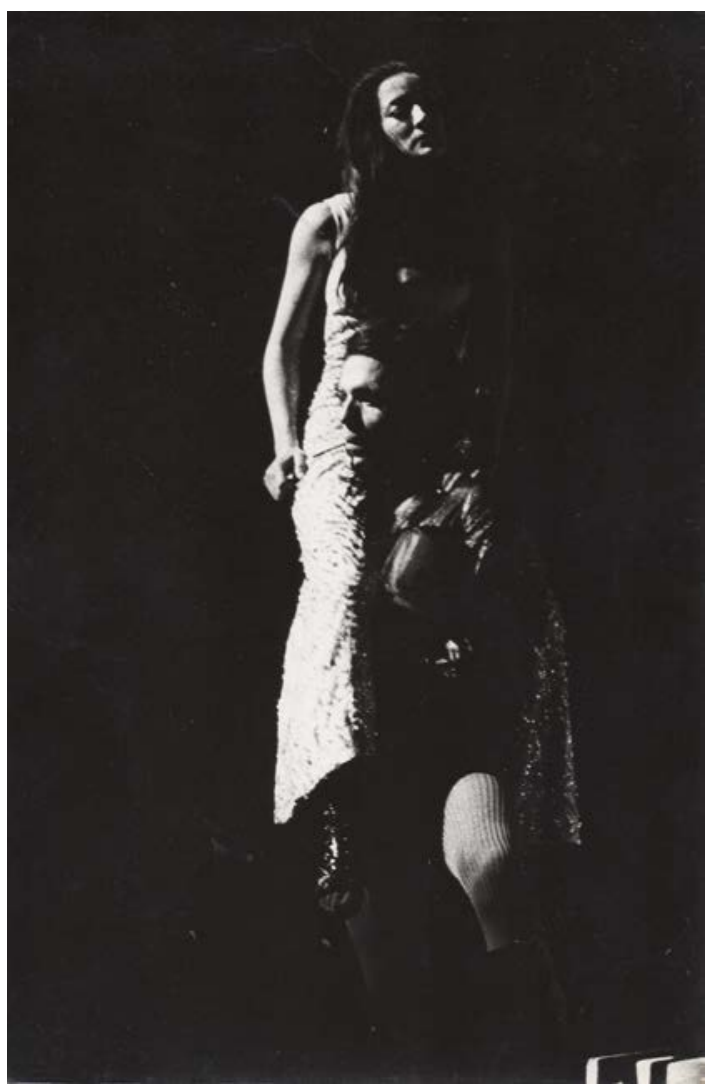

Fedra (Itelman, 1970). Foto de Hector Boetto. Gentileza de José Carlos Campitelli.

La obra se presentó el 27 de junio de 1970 en un preestreno para "funcionarios, autoridades y miembros del gremio artístico" (Szuchmacher, 2002: 155). Según Aráiz, "público y prensa acogieron Fedra con la frialdad del pasmo y las autoridades del Teatro manifestaron que era poco conveniente continuar con las representaciones" (1993: 16). Se produjo entonces un intento de censura que motivó una fuerte réplica por parte de la coreógrafa. Según el mensaje que le hicieron llegar a Ana Itelman por intermedio de Oscar Aráiz, las autoridades habían decidido dejar de representarla por su "falta de decoro", "falta de buen gusto" y "falta de valor artístico" (Szuchmacher, 2002: 153). Como respuesta, la coreógrafa redactó una carta dirigida al Consejo Directivo y a la Comisión Asesora del Teatro con fecha del 24 de julio de 1970, defendiendo su creación. Retrospectivamente, la respuesta de Itelman llama la atención por su audacia. Luego de contestar las acusaciones que se realizaban en contra de la obra, la coreógrafa invierte el sentido de la afrenta acusando ella misma a quienes intentaban censurarla. En este sentido escribía:

La decisión de las autoridades comporta una restricción a la libertad teatral [...] Al asumir las autoridades la responsabilidad enunciada, han colocado al Teatro en una posición muy delicada: la de convertirlo en un Teatro censurado, coartado, limitado. El Teatro Municipal General San Martín cumplía una obra fundamental cuando brindaba al público argentino, sin retaceos ni evaluaciones apriorísticas, sin prejuicios ni valoraciones estéticas preconcebidas, obras de artistas de diferentes tendencias estéticas. Es de lamentar que las autoridades se reserven el derecho de cercenar este privilegio al ciudadano argentino que es, en primera y en última instancia, quien sostiene al Teatro que sus autoridades actuales dirigen [...] Las autoridades han incorporado a la conducción del teatro un elemento nuevo: el autoritarismo (Szuchmacher, 2002: 154). 
Luego de estas palabras, Itelman proponía realizar un nuevo ensayo general frente a las autoridades y a periodistas especializados para decidir de manera colectiva el destino de la obra, intimándolos a darle una respuesta a los cinco días de haber recibido la carta. Su respuesta parece negar implícitamente el contexto político en el cual se expresa. Su referencia a la figura del ciudadano y su extrañamiento frente al autoritarismo suponen un contexto democrático cuando en realidad hacía cuatro años que Argentina estaba bajo una dictadura. Debemos tener en cuenta que la dictadura de los años 60 no tuvo el nivel de represión y violencia del Proceso de Reorganización Nacional que comenzó en 1976. En los 60, nada hacía suponer que Argentina iba a sufrir en la siguiente década una de las dictaduras más sangrientas de toda Latinoamérica y que iba a ser víctima de un terrorismo de Estado que generaría la desaparición forzada de 30.000 ciudadanos. De cualquier manera, la intervención de Itelman representa un gesto de mucho coraje.

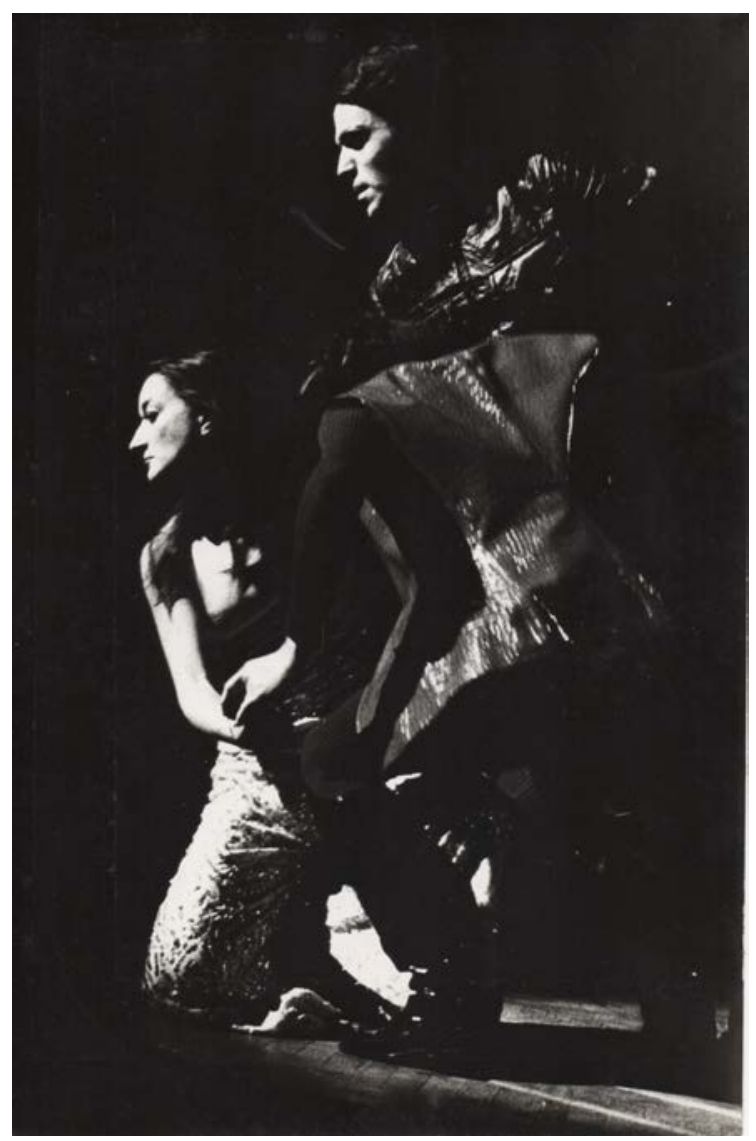

Fedra (Itelman, 1970). Foto de Hector Boetto. Gentileza de José Carlos Campitelli.

Asimismo, la carta de la coreógrafa no es inocente. Su respuesta actúa intencionalmente en ese terreno indefinido en el que la censura, como práctica represiva del estado autoritario, intentaba proyectarse al plano individual como autocensura para evitar asumir el costo político de sus acciones. La estrategia de intervención de Itelman implica también la apelación a una suerte de utopía. El sustrato ideológico de su intervención es la concepción del arte como una práctica aislada de la sociedad, la idea de l'art pour l'art. Para Itelman, el autoritarismo entra al teatro recién a través de la censura de Fedra. La afirmación es evidentemente errada, ya que los artistas son ante todo sujetos inmersos en una realidad social y en una dictadura la libertad se encuentra cercenada. Los artistas no eran realmente libres, Itelman no ignora esta realidad. La intervención es fascinante, no por su afirmación pseudo-naive de un 
arte neutral y apolítico, sino por su intención de utilizar ese discurso para reclamar un espacio de libertad desde donde actuar políticamente. Es un gesto utópico, pero a la vez una acción política que interpreta perfectamente las posibilidades de acción que le brinda ese contexto histórico. La idea de concebir el acceso al teatro como un derecho del ciudadano define, a su vez, al arte como a un espacio constitutivo de la práctica democrática, otro elemento que socava implícitamente los fundamentos de la autoridad militar.

\section{El final}

A fines de ese mismo año, el Ballet del San Martín recibe una invitación por parte de Norman Singer, director del City Center de Nueva York, para realizar presentaciones en EEUU. La embajada de ese país invita a Oscar Aráiz a visitar la ciudad en enero de 1971 y, durante ese viaje, el coreógrafo recibe la noticia de que los contratos de los integrantes del Ballet del San Martín no serían renovados. Se había producido un nuevo cambio de autoridades, el Secretario Municipal de Cultura, Alberto Obligado, había renunciado para asumir un cargo en la UNESCO y su reemplazante Francisco Carcavallo, un ex empresario teatral, había designado a la veterana actriz Iris Marga como directora artística del Teatro. Las nuevas autoridades se orientaron hacia un teatro más tradicional y comercial, y tomaron la decisión de interrumpir la experiencia del Ballet del San Martín argumentando problemas presupuestarios (Diario Buenos Aires Herald, 7 de febrero de 1971). La compañía logró obtener una nueva contratación recién en junio de 1971, bajo la órbita de la Dirección General de Cultura, en el Teatro Nacional Cervantes, gracias al apoyo que había recibido por parte del funcionario Ricardo Freixá (Isse Moyano, 2006: 113). Sin embargo, esos contratos caducaron en enero de 1973 y ya no fueron renovados. Sería recién en 1977, gracias a la creación del Grupo de Danza Contemporánea, por iniciativa del por entonces Director del Teatro San Martín, Kive Staiff, que este género volvería a tener apoyo institucional. Las condiciones políticas y administrativas determinaron, sin lugar a dudas, el desarrollo de la danza contemporánea en la ciudad de Buenos Aires, condicionando las prácticas, pero también generando una constante inestabilidad institucional que interrumpió procesos creativos sumamente valiosos.

Sea por los intentos de censura explícitos o sutiles a los que fueron expuestos, sea por la actitud reivindicativa de los medios de comunicación gráfica que denunciaron su exclusión o por las respuestas por parte de los artistas, las obras Consagración de la Primavera y Fedra devinieron acontecimientos políticos más allá de las intenciones explícitas de sus creadores o de su impronta militante. Lo político emerge en estas obras a partir de una disputa por la sexualidad y, en ese sentido, por la construcción de la subjetividad, es decir, "de la manière dont nous nous comportons, dont nous prenons conscience de nous-mêmes [de la manera en que nos comportamos, en que tomamos consciencia de nosotros mimos]" (Foucault, 2001b: 570). Para Foucault, la relación entre sexualidad y política se expresa en la forma en la que el poder produce los cuerpos. Desde la época moderna, el cuerpo humano ha sido construido como fuerza de trabajo integrada a un sistema de producción. Esa construcción del cuerpo comienza a cuestionarse durante los años 60. De este modo, como afirma Foucault, "c'est cette lutte pour le corps qui fait que la sexualité est un problème politique [es esa lucha por el cuerpo lo que hace que la sexualidad sea un problema político]" (2001a: 1405).

La sexualidad como tema de indagación en ambas obras constituye una herramienta para cuestionar la producción de subjetividad característica de ese momento histórico. La dictadura se propuso construir un cuerpo moral, disciplinado, un 
obrero y una obrera dócil. La lucha por la liberación del deseo y del placer que emprenden estas obras se enmarca en una estrategia colectiva de subversión del poder dictatorial y de recuperación del cuerpo. Más allá de que estas producciones artísticas hayan tenido una relación conflictiva con la militancia de izquierda antiimperialista, la subversión utópica actuó a favor del proceso revolucionario que se intentó desarrollar ya que, como afirma Muñoz, los "sentimientos utópicos" son algo "indispensable to the act of imaging transformation [indispensable para el acto de imaginar la transformación]" (2009,9). 


\section{Bibliografía}

》 Agamben, G. (1999). Potentialities: Collected Essays in Philosophy. Stanford, CA: Stanford University Press.

》Andújar, A. et al. (2009). De minifaldas, militancias y revoluciones. Buenos Aires: Ediciones Luxemburg.

"Ansaldi, W. (2004). "Matriuskas de terror. Algunos elementos para analizar la dictadura argentina dentro de las dictaduras del Cono Sur." En Pucciarelli, A. (coord.), Empresarios, tecnócratas y militares. La trama corporativa de la última dictadura. (pp. 27-52). Buenos Aires: Siglo XXI.

» Aráiz, O. (1993). “El comienzo." En VV.AA., Ballet contemporáneo. 25 años en el San Martín. Buenos Aires: Teatro Municipal General San Martín.

»Avellaneda, A. (1986). Censura, autoritarismo y cultura: Argentina 1960-1983. Buenos Aires: Centro Editor de América Latina.

"Buch, E. (2001). "El caso Bomarzo: Ópera y dictadura en los años sesenta". Boletín del Instituto de Historia Argentina y Americana "Dr. Emilio Ravignani” (23), 109-137.

»Buch, E. (2003). The Bomarzo affair: Ópera, perversión y dictadura. Buenos Aires: Adriana Hidalgo Editora.

»Calvera, L. (1990). Mujeres y feminismo en la Argentina. Buenos Aires: Grupo Editor Latinoamericano.

»Dolan, J. (2005). Utopia in Performance: Finding Hope at the Theater. Michigan: University of Michigan Press.

» Falcoff, L. (2008). “La danza moderna y contemporánea”. En Historia general de la danza en la Argentina. (pp. 231-321). Buenos Aires: Fondo Nacional de las Artes.

» Felitti, K. (2012). La revolución de la píldora. Sexualidad y política en los sesenta. Buenos Aires: Edhasa.

»Fiadeiro, J. y Paula Caspao. (2016). "O fim dos principios”. En Xavier, J., Meyer, S y Torres, V. (dir.), Tubo de Ensaio. Florianópolis: Instituto Meyer Filho.

»Fortuna, V. (2013). Poner el cuerpo: Buenos Aires Contemporary Dance and the Politics of Movement. Tesis de Doctorado, Northwestern University.

»Foucault, M. (2001a), Dits et écrits I. Paris: Gallimard.

» Foucault, M. (2001b). Dits et écrits II. Paris: Gallimard.

» Franko, M. (2019). Danzar el modernismo/Actuar la política. Buenos Aires: Miño y Dávila.

" García Canclini, N. (2005). Hybrid Cultures: Strategies for Entering and Leaving Modernity. Minneapolis: University of Minnesota Press.

»Gusdorf, G. (1960). Mito y metafísica: introducción a la filosofía. Buenos Aires: Nova.

» Herrera, M. J. (2010). POP! La consagración de la primavera. Buenos Aires: Fundación OSDE. 
»Invernizzi, H. y Gociol, J. (2003). Un golpe a los libros: represión a la cultura durante la última dictadura militar. Buenos Aires: Eudeba.

»Isse Moyano, M. (2006). La Danza Moderna Argentina cuenta su Historia: historias de vida. Buenos Aires: Artes del Sur.

» Jouhaud, C. (2009). Mazarinades. La Fronde des mots. Paris: Flammarion.

» Kaehler, S. (2012). Asociación Amigos de la Danza 1962/1966. Buenos Aires: Libros del Rojas.

"King, J. (2007). El Di Tella y el desarrollo cultural argentino en la década del sesenta. Buenos Aires: Asunto Impreso.

"Kehrer, B. (1988). "Promenade au pays d'Araiz." En Buffat, Serge. Oscar Araiz. Carnets de danse. Genève 1980-1988. (pp. 11-18). Genève: Favre.

»Longoni, A. y Mestman, M. (2002). Del Di Tella a “Tucumán arde”. Vanguardia artística y política en el 68 argentino. Buenos Aires: Eudeba.

"Longoni, A. (2014). Vanguardia y revolución. Arte e izquierdas en la Argentina de los sesenta-setenta. Buenos Aires: Ariel.

»Mafud, J. (1966). La revolución sexual argentina. Buenos Aires: Americalee.

"Osswald, D. (2010). “Las narrativas de 'las pioneras'. Cuestiones de género y moralidades en el desarrollo de la danza moderna en la Argentina (19401960)". Revista Latinoamericana de Estudios sobre Cuerpos, Emociones y Sociedad (4), 41-51.

»Perlongher, N. (2008). Prosa plebeya: ensayos 1980-1992. Buenos Aires: Colihue.

"Pujol, S. (2003). “Rebeldes y modernos. Una cultura de los jóvenes”. En James, D. (dir.), Nueva Historia Argentina. Violencia, proscripción y autoritarismo (19551976). Buenos Aires: Editorial Sudamericana.

»Ricoeur, P. (1997). L'idéologie et l'utopie. Paris: Seuil.

"Sidicaro, R. (2004). "Coaliciones golpistas y dictaduras militares: el "proceso" en perspectiva comparada." En Pucciarelli, A. (coord.), Empresarios, tecnócratas y militares. La trama corporativa de la última dictadura. (pp. 53-98). Buenos Aires: Siglo XXI.

"Szuchmacher, R. (2002). Archivo Itelman: Textos de Ana Itelman. Buenos Aires: EUDEBA.

"Tambutti, S. (2000). “Danza Moderna argentina: consolidación y profesionalización” En VV. AA., Siglo XX Argentino. Arte y Cultura. Buenos Aires: Centro Cultural Recoleta.

"Tortti, C. (1999). "Protesta social y nueva izquierda en la Argentina del Gran Acuerdo Nacional." En Pucciarelli, Alfredo (coord.), La primacía de la política. Buenos Aires: Eudeba. 